\begin{tabular}{c} 
Volume and Issues Obtainable at Center for Sustainability Research and Consultancy \\
Review of Politics and Public Policy in Emerging Economies \\
ISSN: 2708-3829 (E): 2708-356X \\
Volume 1: No. 1, June 2019 \\
CSRᄃ \\
Journal homepage: www.publishing.globalcsrc.org/rope \\
\hline
\end{tabular}

\title{
Analytical Effect Of Insurgency On Cowpea (Vigna Spp) Production In Potiskum Local Government Area Of Yobe State, Nigeria
}

\author{
${ }^{1}$ Adamu Usman, ${ }^{2}$ Ali Garba Bawa \\ $1 \& 2$ Department of Agricultural Science Education, School of Vocational Education, Federal College of \\ Education (Technical), Potiskum, Yobe State, Nigeria: usmanadamu347@gmail.com
}

\begin{tabular}{l}
\multicolumn{1}{c}{ ARTICLE DETAILS } \\
\hline History \\
Revised format: May 2019 \\
Available Online: June 2019 \\
\hline Keywords \\
Effect, Insurgency, Cowpea \\
Production
\end{tabular}

\section{JEL Classification:}

D24, D29

\section{ABSTRACT}

This study analyzed the effect of insurgency on cowpea production in Potiskum Local Government Area of Yobe State, Nigeria. This study is quantitative research where 120 cowpea farmers were randomly interviewed using structured response questionnaires. Data were analyzed using descriptive and inferential statistics. The results showed that $35 \%$ of the respondents fell within the age bracket of 28-33 years; males constituted $55 \%$ and $42 \%$ had primary education. The findings further reveaed that $77.50 \%$ perceived the effect of insurgency on their livelihood. Majority up to $70.80 \%$ of the respondents perceived increase in poverty and job loses respectively. Almost $52.5 \%$ of the respondents were affected by the conflicts, then children $21.7 \%$, women $13.3 \%$ and adult men $8.3 \%$. 32.50\% of the respondents lost their houses, $29.20 \%$ lost their livestock, and $16.70 \%$ and $13.30 \%$ lost their crops and sustained body injuries respectively. Majority up to $67.50 \%$ of the respondents suggested that all the methods, $16.70 \%$ suggested military action, $6.70 \%$ negotiation, $5.0 \%$ and $4.20 \%$ of the respondents suggested state of emergency and amnesty respectively. Furthermore, the regression analysis revealed that $74 \%$ variation in output was accounted by the independent variables in the model. However, educational level, sex and income were significant at $\mathrm{p}<0.001$, while household size, farm size and distance from farm to homestead were significant at $p<0.05$. Chi-square analysis revealed that the variables included in the model such as sex, educational level, age, income and distance from farmlands to homestead were significant at $\mathrm{p}<0.05$, with the exception of farm size, marital status and farming experience. The study concluded that insurgency exists in the study area and the effects include loss of lives, crops, and destruction of infrastructures, such as schools, telecommunication mast, mosques, churches, markets and houses. The study recommended that education and employment opportunities be provided to the youths in the study area.

Corresponding author's email address: usmanadamu347@gmail.com

Recommended citation: Usman, A. \& Bawa, A. G., (2019). Analytical Effect Of Insurgency On Cowpea (Vigna Spp) Production In Potiskum Local Government Area Of Yobe State, Nigeria. Review of Politics and Public Policy in Emerging Economies, 1(1), 53-60

DOI: $10.26710 /$ rope.v1i1.1133 


\section{Introduction}

The term Insurgency is defined as a political battle waged among a cooperative or assent or consent populace in order for a group of outsiders to take over or at least undermine the government of a society, city, state or a nation. It is also known by other names such as rebellion, revolution, revolt, uprising, mutiny and riot etc. (Bawa, 2017).

For all insurgencies, conflicts and as for all natural disasters, the most important effects are the suffering, injury and death of men, women and children. The losses in output, means of production and infrastructure seem insignificant in comparison. Yet these material losses are also important, for they undermine the ability of insurgent survivors to subsist and recover. This is the most obvious in agriculture, where the destruction of crops and livestock, results at best, to reduced food security and, at worst, in famine and death. Indeed, in many cases, deaths resulting indirectly from insurgency that is famine, a typical example exceed deaths from direct violence. The estimation of material losses, narrow as it is, represents an important aspect of assessing the severity of a insurgency. It also provides a guide to the design of long-term policy for dealing with uprising situations (Jimmy, 2015).

Insurgency is also having a significant effect on economy because some sectors of activity flourish, while others suffer. For understanding structural problems in developing countries and designing appropriate post-insurgency reconstruction policies, it is essential to understand in what ways insurgency affects the structure of the economy. Insurgency reduces the share of the manufacturing sector in the Gross Domestic Product (GDP), increases the exploitation of some simple natural resources and reduces the production of crops (Bawa, 2017). Insurgency affects the manufacturing sector; industries that are more institutional intensive are the ones that suffer most in conflictive societies. Labour intensive sectors are also negatively affected by insurgencies. It is also found that exporting industries and sectors requiring external financing suffer more during insurgencies (Ernesto and Pedro, 2016).

The center of origin of Cowpea (Vigna unguiculata) is Africa South of the Sahara. There are two likely places of origination which are East and West Africa respectively. There are quite number of species, but the important ones are three: (a) Vigna unguiculata, (b) Vigna sesquipedalis and (c) Vigna catjan. The term cowpea is a common name for Vigna unguiculata, an annual crop of the pea family (Leguminosea), which is mainly planted for its edible beans, which are taking both dry and in the green pods by both humans and animals (livestock). Cowpea is widely grown as subsistence crop for home and for exports, usually in many African countries South of Sahara. They are also grown extensively in Latin America and South East Asia. The major producing countries are: Nigeria, India and Tanzania (Anyanwu, 2015).

Cowpea is one the most widely grown food crops in Africa. It is estimated that more than $90 \%$ of the world cowpea grain production of 5.7 million tonnes is produced in about 10 million hectares in Africa (FAOSTAT, 2015). The crop is most important in the semi-arid and hot areas of Africa where other crops may fail due to poor adaptation to heat, drought and low soil fertility conditions (Gwathmey and Hall, 2016). Among the top six major world cowpea producers, five are located in Africa and include Nigeria, Niger, Burkina Faso, Senegal and Mali (Fery, 2012).

Cowpea is the most important food grain legume which serves as a very cheap source of protein (Bawa, 2017). Potiskum grain market was estimated in 2016 to sell 3500 bags of grain on market day. The market is one of the largest grain markets in North Eastern Nigeria ((Yobe State Diary, 2016). However, insurgencies may affect its production, processing as well as its marketing pattern. Farmers are scared to go to their farms because of fear of possible clash between the insurgents and Nigerian army which most of the times result in the death of so many innocent civilians. Riding motorcycle was completely banned, which resulted into a transportation bottleneck to farmers, to and fro their various farms. Only few farmers could afford to buy car that would be used to transport them to their farms and at times, it is not economically wise to be fuelling car to go to their small farmlands. It is against this background that the study intends to analyzed the level of the effects of insurgency on cowpea farmers in the study area. The 
research would be useful to farmers and other stakeholders. The research would also provide useful information to policy makers, government and non-governmental organizations.

According to Ofuako and Isefe (2017) farmers' perception as to become aware of, through the senses "to see or to understand". He further stated that perception become more and more perfected with age, education and mental development. This is because it now involves more accurate and complete knowledge of the perceived object or action. Perception is defined in terms of respondents' awareness or recognition of situations influencing the success or failure of certain phenomenon.

Cowpea production is the cultivation, processing and marketing of cowpea, cowpea product and by products (Salihu, 2017). Cowpea is the most important food grain legume which serves as a very cheap source of protein. Potiskum grain market was estimated in 2016 to have sold 3500 bags of grain on market days. The market is one of the largest grain markets in North Eastern Nigeria (Yobe State Diary, 2016). However, insurgencies may affect its production, processing as well as its marketing pattern. The study objectives were to; describe the socio-economic characteristics of cowpea farmers in the study area; determine the influences of socio-economic factors on cowpea farmers output; examine the perceived effect of conflict on the livelihood of cowpea farmers; and ascertain the losses due to effect of conflicts on cowpea farmers.

Potiskum Local Government Area was one of the peaceful local governments in Nigeria, where various ethnic groups have been living together without any fear or conflict. Potiskum was known to be a commercial centre of cowpea production and processing in North Eastern Nigeria, but as a result of insurgency, most of the commercial and agricultural activities were significantly crippled, especially the production and processing of cowpea (Salihu, 2017).

\section{Methodology}

Quantitative method (descriptive survey research design) was employed for the study. The population for the study was 412 cowpea farmers drawn from 10 wards in the study area. The sample of the study was 120 respondents drawn using a multi-stage sampling technique. In the first stage, the study area was purposively selected because it was one of the local government area affected by insurgency. In the second stage; 5 wards were randomly selected out of the 10 wards, by the use of flip papers with the names of each ward written and folded on the paper and placed into container and thoroughly mixed. Thereafter, 5 wards were hand-picked without biased. Therefore, a total of 120 cowpea farmers were randomly selected based on proportionate allocation techniques. The study used both primary and secondary sources of data through the administration of structured questionnaires. The questionnaires were divided into four sections based on the objectives that were raised to guide the study. The data collected was analysed using descriptive and inferential statistics such as frequency count, percentage and tables were used in analysing objective i, iii and iv while chi-square test was used to achieve the second objective of the study respectively.

\section{Results and Discussions}

The results and the analysis of data for this study were presented based on the four objectives raised to guide the study as follows:

\subsection{Analytical Effect of Socio-Economic Characteristics (SEC) of Cowpea Farmers in the Study Area}

The results in table 1 , revealed that $80.80 \%$ of the respondents fell within the age bracket of 18-33 years, while $19.20 \%$ were above 34 years. The results implies that most of the respondents were in their active age and are expected to be energetic. This result is closely similar with that of Pur et al. (2016) who related that, majority of the respondents interviewed were between the ages of 35 and below. The results also revealed that males constituted the highest percentage $(55.00 \%)$ than their female counterparts (45.00\%). According to Sulaiman and Ja'afar-Furo (2015), 79.00\% of the farmers interviewed in Bauchi 
state were males. The result further revealed that majority $65.00 \%$ of the respondents were married, $45.00 \%$ were single. It was earlier observed that early marriage is common in this part of the country (Peter, 2002). Almost all 92.50 of the respondents had attended formal education at different levels, 4.20\% never been to school and 3.30\% non-formal education. This result is consistent with Pur et al. (2006) adduced that $97.00 \%$ of the respondents were literate. The result in table 1 revealed that most $88.3 \%$ of the respondents had $0.5-4.0$ hectares and only $11.70 \%$ of the respondents cultivated $4.5-5$ hectares of farmland. This showed that, majority of the farmers are small scale farmers. This is in line with Okunade (2017) who revealed that majority of the farmers in Osun State had farm size between 1and 5 hectares.

\subsection{Analytical Effect of the Infuence of Socio-Economic Characteristics (SEC) on Cowpea Farmers Output in the Study Area}

The findings in table 2 , shows the regression analysis which revealed that $\mathrm{R}^{2}$ value of 0.74 . This implies that, $74.00 \%$ variation on output is as a result of independent variables included in the model and it was confirmed by F- statistic (22.251) and significant at $p<0.001$. However, sex, educational level and income of the farmers were significant at $\mathrm{p}<0.001$. Furthermore, household size, farm size and distance from farm to homestead significantly $\mathrm{p}<0.05$ influence output. The implication is that, any increase in those independent variables will increase output. On the other hand, the coefficient of age of the famers was negative and significant $p<0.05$, implying that, the age of the farmer has an inverse effect on output. As the age of the farmer increases the output decreases. This findings, also agreed with the results obtained by Bawa (2017) obtained the regression analysis which revealed that $\mathrm{R}^{2}$ value of 0.74 . This implies that, $74.00 \%$ variation on output is as a result of independent variables included in the model and it was confirmed by F- statistic (22.251) and significant at $\mathrm{p}<0.001$ respectively.

\subsection{Analytical Relationship Between the Effect of the Perceived Nature of the Conflicts on Livelihood of Cowpea Farmers and Selected Socio-Economic Characteristics (SEC) Variables in the Study Area}

The results in table 3, highligted that majority at $37.50 \%$ of the respondents perceived increase in poverty, $33.30 \%$ of the respondents lost their jobs while $16.70 \%$ and $12.50 \%$ of the respondents had fear of uncertainties as well as food insecurity respectively. Insurgency affects the manufacturing sector; industries that are more institutional intensive are the ones that suffer most in conflictive societies. Labour intensive sectors are also negatively affected by conflict. It is also found that exporting industries and sectors requiring external financing suffer more during conflict (Ernesto and Pedro, 2016).

\subsection{Analytical Effect of the Distributions of Respondents According to Possible Solutions of Insurgency on Cowpea Farmers in the Study Area}

The findings in table 4 , revealed that majority at $67.50 \%$ of the respondents suggested all the methods, $16.70 \%$ suggested military action, $6.70 \%$ negotiation, $5.0 \%$ and $4.20 \%$ of the respondents suggested state of emergency and amnesty should be used respectively. Bawa (2017) also revealed that many strategies had been adopted to curb the insurgency such as dialogues, negotiation, amnesty, militarization, state of emergency etc., education and employment opportunities should be given to the youths in the study area, so that they will not be recruited by insurgents and serve as army of violence. 
Table 1: Analytical Effect of Distribution of Respondents on Socio-Economic Characteristics (SEC) of Cowpea Farmers in the Study Area

\begin{tabular}{|l|c|l|}
\hline Age (years) & Frequency & Percentage \\
\hline $18-23$ & 25 & 20.80 \\
\hline $24-27$ & 30 & 25.00 \\
\hline $28-33$ & 42 & 35.00 \\
\hline $34-$ years above & 23 & 19.20 \\
\hline Sex: & 66 & \\
\hline Male & 54 & 55.00 \\
\hline Female & & 45.00 \\
\hline Marital status: & 65 & \\
\hline Married & 55 & 54.20 \\
\hline Single & 5 & 45.80 \\
\hline Level of Education: & 4 & 4.20 \\
\hline Never been to school & 13 & 3.30 \\
\hline Non formal & 51 & 10.80 \\
\hline Primary education & 47 & 42.50 \\
\hline Secondary education & & 9.20 \\
\hline Tertiary education & 35 & \\
\hline Farm size: (ha) & 28 & 29.20 \\
\hline $0.5-1$ & 25 & 23.30 \\
\hline $1.5-2$ & 18 & 15.00 \\
\hline $2.5-3$ & & \\
\hline $3.5-4$ & & 20.70 \\
\hline $4.5-5$ & & \\
\hline
\end{tabular}

Total

120100.00

Source: Bawa (2017).

Key:

Ha: hectare (s) 
Table 2: Analytical Effect of the Infuence of Socio-Economic Characteristics (SEC) on Cowpea Farmers Output in the Study Area

\begin{tabular}{llll}
\hline Variables & Coefficients & Std. Error & t-value \\
\hline Constant & 4.116 & 0.426 & $9.671^{* * * *}$ \\
Sex $\left(\mathrm{X}_{1}\right)$ & 0.365 & 0.107 & $3.400^{* * *}$ \\
Years of education $\left(\mathrm{X}_{2}\right)$ & 0.035 & 0.011 & $3.263^{* * *}$ \\
Age $\left(\mathrm{X}_{3}\right)$ & 0.210 & 0.485 & $-2.314^{* *}$ \\
House hold size $\left(\mathrm{X}_{4}\right)$ & 0.047 & 0.017 & $2.767^{* *}$ \\
Farming experience $\left(\mathrm{X}_{5}\right)$ & 0.020 & 0.025 & $0.793^{\mathrm{NS}}$ \\
Income $\left(\mathrm{X}_{6}\right)$ & 0.039 & 0.010 & $3.990^{* * *}$ \\
Farm size $\left(\mathrm{X}_{7}\right)$ & 0.216 & 0.091 & $2.378^{* *}$ \\
Marital status $\left(\mathrm{X}_{8}\right)$ & 0.027 & 0.044 & $0.621^{\mathrm{NS}}$ \\
Distance from homestead $\left(\mathrm{X}_{9}\right)$ & 0.026 & 0.013 & $2.062^{* *}$ \\
$\mathrm{R}^{2}$ & 0.74 & & \\
F- statistic & $22.251^{* * *}$ & & \\
\hline Sourc Bawa & &
\end{tabular}

Source: Bawa (2017).

Keys:

$* * *$ significant at $\mathrm{p}<0.001$

$* *$ significant at $\mathrm{p}<0.01$

NS = Not significant.

Table 3: Analytical Relationship Between the Effect of the Perceived Nature of the Conflicts on Livelihood of Cowpea Farmers and Selected Socio-Economic Variables in the Study Area

\begin{tabular}{lccll}
\hline Variables & Chi-value & P Value & DF & DECISION \\
\hline Sex & 56.246 & 0.030 & 19 & $\mathrm{~S}$ \\
Education level & 97.155 & 0.011 & 76 & $\mathrm{~S}$ \\
Age & 77.658 & 0.025 & 57 & $\mathrm{~S}$ \\
Farm size & 1.374 & 0.721 & 95 & $\mathrm{NS}$ \\
Income & 85.807 & 0.026 & 39 & $\mathrm{~S}$ \\
Marital status & 4.534 & 0.955 & 38 & $\mathrm{NS}$ \\
Distance to homestead & 91.503 & 0.014 & 95 & $\mathrm{~S}$ \\
Farming experience & 1.346 & 0.775 & 98 & $\mathrm{NS}$ \\
\hline
\end{tabular}

Source: Bawa (2017).

\section{Keys:}

NS - Not Significant

$\mathbf{S}$ - Significant level $0.5 \%$

Table 4: Analytical Effect of the Distributions of Respondents According to Possible Solutions of Insurgency on Cowpea Farmers in the Study Area

\begin{tabular}{lcc}
\hline Solutions & Frequency & Percentage \\
\hline & 8 & 6.70 \\
Negotiation & 5 & 4.20 \\
Amnesty & 20 & 16.70 \\
Military action & 6 & 5.00 \\
State of emergency & 81 & 67.50 \\
All of the above & $\mathbf{1 2 0}$ & $\mathbf{1 0 0 . 0 0}$ \\
Total & &
\end{tabular}

Source: Bawa (2017). 


\section{Conclusion}

Based, on the results of this study, it was revealed that conflicts exist in the study area and the effect include loss of human lives, crops, livestock and destruction of structures like government buildings, schools, power plant, bridges, communication facilities, mosques, churches, markets, houses among others. The implication of this is cowpea farmers output have reduced drastically and dwindling effects on livelihood in the study area is beyond expectation The analytical estimate have put death toll to more than fifteen thousand humans. This research believed that the terrorists were youths who are miscreants, downtrodden, un-informed and poor, who need empowerment from government and well to do citizens in Nigeria and the wider world.

\section{Recommendations}

The following recommendations were made based on the findings of the study:

- The use of strategies like dialogues, negotiation, amnesty, militarization, state of emergency etc have proved effective in reducing insurgency in the study area.

- Education and employment opportunities should be given to the youths in the study area, so that they will not be recruited by insurgents and serve as army of violence.

- Cowpea producers and processors should be given loans and agricultural inputs by government, in order to boost the production and processing of cowpea in order to reduce the losses encountered.

- Compensation package and agricultural extension services should be improved to teach farmers on new ways of farming techniques in cowpea production.

\section{References}

Anyanwu, A. (2015). Agricultural Science for Schools and Colleges. Onitsha: Evans Publishers, Nigeria. pp. 23.

Bawa, A. G. (2017). Analysis of Effects of Insurgency on Cowpea Prodution in Potiskum Local Government Areaof Yobe State, Nigeria. Unpublished Master's Thesis, Abubakar Tafawa Balewa University, Bauchi.

Ernesto, D. B. \& Pedro D. B. (2016).Workers, Warriors, And Criminals: Social Conflict In General Equilibrium, Journal of the European Economic Association, European Economic Association, 9 (4): 646-677.

FAOSTAT (2015). World Cowpea Production. Retrieved on 10/10/2016 from: http://faostat.fao.org.

F Fery, R. L. (2012). New opportunities in Vigna. Pp. 424 - 428. In J. Janick and A.Whipkey, eds. Trends in new crops and new uses. ASHS Press, VA

Gwathmey, C.O. \& Hall, A. E., (2016). Adaptation to mid-season drought of cowpea genotypes with contrasting senescence traits. Crop Sci. 32: 773-778.

Ji Jimmy, C. (2015). First step toward peace is eradicating hunger. International Herald Tribune, 17 June 2015.

Ofuoku, A. U. and Isefe, B. I. (2017). Causes, effect and resolution of farmers-normadic cattle herders conflict in Delta State, Nigerian International Journal of Sociology and Anthropology, 1 (2): 047 054.

Okunade, E. O. (2017) . Effectiveness of Extension Teaching Methods in Acquiring Knowledge, Skill and Attitude by Women Farmers in Osun State, Nigeria. Retrieved from: http://www.eurojournals.com/finance.htm on December 2nd 2011.European Journal of Social Sciences,4(2): 22- 0.

Pur, J. T., Gaya, H. I. M. \& Benisheik, K. (2016). Cases of farmer-pastoralist conflict in Borno State, Nigeria. Journal of Agricultural Extension. 9 (2). 87 - 94.

Salihu, M. N. (2017). Tree crop production for schools and colleges. Unpublished manuscript. Pp. 1 - 6.

Sulaiman, A. \& Ja'afar-furo, M. (2015). Economic effects of farmer-grazier conflict in Nigeria: A case study of Bauchi state. Trends in Agricultural Economics. 3. 147-157.

Yobe State Diary (2016). (3rd edition). Yobe state statistics. Damaturu: State Government Printing Press. 
